\title{
Growth and Mineral Composition of Newly Planted Apple Trees Following Fertigation with N and $\mathbf{P}$
}

\author{
G.H. Neilsen ${ }^{1}$, P. Parchomchuk ${ }^{1}$, W.D. Wolk ${ }^{2}$, and O.L. Lau ${ }^{2}$ \\ Agriculture Canada Research Station, Summerland, B.C. VOH 1Z0, Canada \\ Additional index words. fertilization, 'Jonagold', 'McIntosh', $\mathrm{Ca}\left(\mathrm{NO}_{3}\right)_{2}$, urea, $\mathrm{NH}_{4} \mathrm{NO}_{3}$, phosphoric acid, fruit quality
}

\begin{abstract}
Newly planted 'Jonagold' and 'McIntosh' apple (Malus domestica Borkh.) on M.26 fertigated with $\mathrm{Ca}\left(\mathrm{NO}_{3}\right)_{2}$ showed increased early tree vigor and leaf Ca concentration but decreased leaf $\mathrm{Mg}$ and Mn compared to trees fertigated with urea or $\mathrm{NH}_{4} \mathrm{NO}_{3}$. Fertigation with $\mathrm{P}$ increased early tree vigor, leaf and fruit $\mathrm{P}$ concentration, and decreased leaf $\mathrm{Mn}$ in the first year relative to a single planting hole application of granular $\mathrm{P}$. Increased fruit Ca concentration in 'Jonagold' in one year was associated with the use of $\mathrm{Ca}\left(\mathrm{NO}_{3}\right)_{2}$ and fertigation of $\mathrm{P}$. Fruit quality was generally unaffected by the experimental treatments.
\end{abstract}

Addition of soluble fertilizers to irrigation water (fertigation) has attracted increasing research attention in major fruit growing areas worldwide (Haynes, 1985). Comparisons with standard broadcast fertilizer applications have been emphasized (Goode et al., 1978), but rate (Smith et al., 1979), chemical form (Klein and Spieler, 1987), and schedule of fertilizer application (Bussi et al., 1991) have also been studied.

Nitrogen is quantitatively the most important fertilizer applied in Pacific Northwest orchards, so comparisons of forms of soluble $\mathrm{N}$ would be most pertinent. Assessing the effects of fertigation with $\mathrm{Ca}\left(\mathrm{NO}_{3}\right)_{2}$ is of interest as a result of conflicting assertions regarding its benefits (Raese and Staiff, 1983) or lack of effect (Miller and Glenn, 1985) on fruit quality. High rates of granular monoammonium phosphate (MAP) incorporated directly into planting holes, especially under replant conditions, have improved vigor (Neilsen and Yorston, 1991) and precocity of apple trees (Neilsen et al., 1990). Many local orchardists currently apply MAP to the planting hole when replanting. Little is known about the effects of fertigation with $\mathrm{P}$, despite its ease of application.

This study reports the effects on vigor, nutrition, and fruit quality of fertigation with $\mathrm{N}$ and $\mathrm{P}$ during the establishment years of newly planted 'McIntosh' and 'Jonagold' apple trees on $\mathrm{M} .26$ rootstock.

\section{Materials and Methods}

The experiment, which was established in a commercial orchard in Apr. 1988, consisted of offset double rows, $1.5 \mathrm{~m}$ apart, with 'Jonagold' or 'McIntosh' trees on M.26 rootstock separated by $1.5 \mathrm{~m}$ within row and with $4.0 \mathrm{~m}$ separation between the sets of double rows. A factorial arrangement of treatments was used, consisting of the six combinations of three forms of fertigation with $\mathrm{N}$ [urea, $\mathrm{NH}_{4} \mathrm{NO}_{3}$, and $\mathrm{Ca}\left(\mathrm{NO}_{3}\right)_{2}$ ] and two methods and timing of $\mathrm{P}$ application (single planting hole and annual fertigation). Treatments were applied randomly with two replicates of 'Jonagold' and one replicate of 'McIntosh'

Received for publication 25 Mar. 1992. Accepted for publication 29 July 1992. Contribution no. 809 of Agriculture Canada Research Station, Summerland, B.C. We acknowledge the technical assistance of B. Drought. M. Schulze, and several summer students. The cost of publishing this paper was defrayed in part by the payment of page charges. Under postal regulations, this paper therefore must be hereby marked advertisement solely to indicate this fact.

${ }^{1}$ Research Scientists.

${ }^{2}$ Okanagan Federated Shippers Assn. Kelowna, B.C. located in the pollenizer rows of the 'Jonagold' orchard. Measurements and samples were taken from the first 10 trees along each of the double rows for all treatments.

In each year, $\mathrm{N}$ was applied at $57 \mathrm{~g} \mathrm{~N} /$ tree using urea $(46 \mathrm{~N}$ OP-OK), $\mathrm{NH}_{4} \mathrm{NO}_{3}(34 \mathrm{~N}-0 \mathrm{P}-0 \mathrm{~K})$, or $\mathrm{Ca}\left(\mathrm{NO}_{3}\right)_{2} \cdot \mathrm{H}_{2} \mathrm{O}(15.5 \mathrm{~N}-0 \mathrm{P}-$ $\mathrm{OK})$. In the 1 st year only, the amount of $\mathrm{N}$ applied via the various forms was reduced to adjust for the $\mathrm{N}$ present in the two ammonium phosphate-P treatments. Thus, $40 \mathrm{~g} \mathrm{~N}$ was added to the $17 \mathrm{~g} \mathrm{~N}$ and $36 \mathrm{~g}$ of P/tree applied as $150 \mathrm{~g}$ of monoammonium phosphate $(11 \mathrm{~N}-24 \mathrm{P}-0 \mathrm{~K})$ uniformly mixed in the planting hole treatment (P1), while $32.5 \mathrm{~g} \mathrm{~N}$ was added to the $24.5 \mathrm{~g} \mathrm{~N}$ and $36 \mathrm{~g}$ of P/tree applied in the fertigated ammonium polyphosphate $(10 \mathrm{~N}-15 \mathrm{P}-0 \mathrm{~K})$ treatment $(\mathrm{P} 2)$. In years 2 and 3 , no additional $\mathrm{P}$ was applied to $\mathrm{P} 1$, whereas for $\mathrm{P} 2, \mathrm{P}$ was applied as phosphoric acid $(0 \mathrm{~N}-30 \mathrm{P}-0 \mathrm{~K})$ at the reduced rate of $18 \mathrm{~g} \mathrm{P} /$ tree. Thus, $\mathrm{N}$ treatments in years 2 and 3 were comprised wholly of the appropriate form of $\mathrm{N}$ since no $\mathrm{N}$ was added with the $\mathrm{P}$ fertilizer. All fertigation treatments were applied in eight equal weekly portions during May and June each year. Phosphorus fertilizers and $\mathrm{Ca}\left(\mathrm{NO}_{3}\right)_{2} \cdot \mathrm{H}_{2} \mathrm{O}$ were applied separately due to their formation of a precipitate when mixed together.

Irrigation was provided daily for $4 \mathrm{~h}$ during each growing season $\left(\approx 1\right.$ May to 1 Oct.) through one 4 liter $\cdot \mathrm{h}^{-1}$ trickle irrigation emitter per tree, located within $20 \mathrm{~cm}$ of the tree.

Other orchard cultural management was undertaken by the cooperating orchardist who generally followed commercial recommendations. According to local recommendations [British Columbia Ministry of Agriculture and Fisheries (BCMAF), 1989], $\mathrm{Zn}$ was applied at 0.7 or $1.1 \mathrm{~kg} \mathrm{Zn/ha} \mathrm{per} \mathrm{year} \mathrm{as} \mathrm{Zn50} \mathrm{(Nu-}$ traspray, $50 \% \mathrm{Zn}$, Leffingwell, Brea, Calif.) with two or three applications annually at tight cluster and at petal fall. NutraPhos 24 (10.5\% P, 20\% Ca, 6\% S, and 12.0\% Zn, Leffingwell) was applied at the same times as $\mathrm{Zn} 50$ at rates of $3.6 \mathrm{~kg} \cdot \mathrm{ha}^{-1}$ per spray. The dilute early $\mathrm{P}$ sprays were unlikely to measurably affect leaf or fruit $\mathrm{P}$ concentration due, in part, to rapid translocation of $\mathrm{P}$ from leaves (Yogaratham et al., 1981). In 1989, the first year of fruiting, $10 \mathrm{Ca}$ sprays were applied at $5.6 \mathrm{~kg}$ $\mathrm{CaCl}_{2} /$ ha per spray in August and September, after leaf sampling. In 1990, five spray applications were made at the same rate during the same time interval. With the frequency of sprays used, we assumed that fruit $\mathrm{Ca}$ concentration was not differ-

Abbreviations: MAP, monoammonium phosphate; SSC, soluble solids concentration. 
entially affected among experimental treatments. Thus, for the $\mathrm{Ca}\left(\mathrm{NO}_{3}\right)_{2}$ treatment, the effect of early season fertigation with $\mathrm{Ca}$ was measured in an orchard where late-season $\mathrm{Ca}$ sprays were applied.

In mid-July each year, 1988-90, composite leaf samples, consisting of 30 leaves per treatment-replicate from the midthird portion of extension shoots of the current year, were collected from 20 trees (first 10 trees of each double row). Calcium, $\mathrm{Mg}, \mathrm{K}, \mathrm{Mn}, \mathrm{Zn}, \mathrm{Fe}$, and $\mathrm{Cu}$ were determined via atomic absorption spectrophotometry, while $\mathrm{N}$ and $\mathrm{P}$ were determined calorimetrically as described by Neilsen and Yorston (1991).

Trunk cross-sectional areas were calculated from trunk diameter measurements made at $0.3 \mathrm{~m}$ height at planting time in Apr. 1988 and subsequently in early Spring 1989-91.

In Oct. 1989 and 1990, immediately before final commercial harvest, 'Jonagold' fruit samples were collected from the experimental plots. In the first fruiting year (1989), a box of fruit was randomly collected from the first 10 trees for each row, separately for each treatment-replicate, for a total of 24 box samples. In 1990, a single box of fruit was randomly collected from the first 10 trees from both double rows for each of the 12 treatment-replicates.

Fruit samples were placed in 0C air storage for 4 months and then ripened for 7 days at 20C. A random sample of 25 fruit was rinsed under running, distilled water and air dried. Stems and seeds were removed and opposite, unpeeled quarters were blended with 1.5 times their weight of distilled water. A 150$\mathrm{ml}$ subsample was further homogenized with a high-speed tissue homogenizer. A weighed 9-ml aliquot of homogenized slurry was digested in $5.4 \mathrm{ml}$ of concentrated $\mathrm{H}_{2} \mathrm{SO}_{4}$ containing $\mathrm{Na}_{2} \mathrm{SO}_{4}$ $(1.8 \mathrm{~g}), \mathrm{Cu}\left(0.36 \mathrm{ml}\right.$ of $25 \% \mathrm{CuSO}_{4}$ solution), and $\mathrm{Se}(0.67$ g.liter ${ }^{-1}$ ) at $380 \mathrm{C}$ for $1 \mathrm{~h}$. Calcium, $\mathrm{Mg}$, and $\mathrm{K}$ were determined on the extracts via atomic absorption spectroscopy. Nitrogen and $\mathrm{P}$ were determined via calorimetric methods as previously referenced. The remaining stored fruit were evaluated for incidence of rot or the development of storage disorders, including internal breakdown, bitter pit, and core browning. Flesh firmness (opposite-pared sides of each fruit tested with a MagnessTaylor penetrometer, $11.1 \mathrm{~mm}$ tip), soluble solids concentration (SSC; refractometry), and titratable acidity (titration of $15 \mathrm{ml}$ of juice with $0.1 \mathrm{~N} \mathrm{NaOH}$ to $\mathrm{pH} 8.1$ ) were determined (Lau, 1983). Yield was not measured as a consequence of the multiple picks undertaken by the cooperating orchardist.

A preliminary analysis of variance (ANOVA) was done on leaf-nutrient concentrations and trunk cross-sectional areas to test for a cultivar $\mathrm{x}$ treatment interaction. Since there was no significant interaction, these data were subjected to ANOVA, [factorial design $=$ three forms of fertigated $\mathrm{N} \times$ two times and methods of $\mathrm{P}$ application $\mathrm{x}$ three replicates (blocks)]. Fruit mineral concentration and quality characteristics were measured only on 'Jonagold' fruit so that a cultivar $\times$ treatment interaction was not relevant and ANOVA was undertaken with two replicates and two subsamples (24 total samples) in 1989 and with two replicates (12 samples) in 1990 for these variables. Percent values were arcsine transformed before variance analysis. A Duncan's multiple range test was used to separate means only when ANOVA indicated significant effects were measured.

\section{Results and Discussion}

Calcium( $\left.\mathrm{NO}_{3}\right)$ - $\mathrm{N}$ fertigated trees were larger at the end of the second growing season than $\mathrm{NH}_{4} \mathrm{NO}_{3}-\mathrm{N}$ fertigated ones (Table
Table 1. Effect of form of $\mathrm{N}$ and type of $\mathrm{P}$ application on average trunk cross-sectional area during the first three growing seasons for 'Jonagold' and 'McIntosh' apples on M.26 rootstock.

\begin{tabular}{|c|c|c|c|c|}
\hline \multirow[b]{3}{*}{ Fertilizer treatment } & \multicolumn{4}{|c|}{ Trunk cross-sectional area $\left(\mathrm{cm}^{2}\right)$} \\
\hline & \multirow{2}{*}{$\begin{array}{l}\text { Planting } \\
\text { time }\end{array}$} & \multicolumn{3}{|c|}{ Yr } \\
\hline & & 1 & 2 & 3 \\
\hline \multicolumn{5}{|l|}{ Form of $\mathrm{N}^{\mathrm{z}}$} \\
\hline Urea $(46-0-0)$ & 1.5 & 3.4 & $5.5 a^{x}$ & 7.3 \\
\hline Ammonium nitrate $(34-0-0)$ & 1.5 & 3.4 & $5.1 \mathrm{~b}$ & 6.8 \\
\hline Calcium nitrate $(15.5-0-0)^{\prime}$ & 1.5 & 3.7 & $5.8 \mathrm{a}$ & 7.5 \\
\hline Statistical significance & NS & NS & $*$ & NS \\
\hline \multicolumn{5}{|l|}{$\mathrm{P}$ application ${ }^{\mathrm{y}}$} \\
\hline Planting hole & 1.5 & 3.4 & 5.2 & 6.9 \\
\hline Fertigated (annual) & 1.5 & 3.6 & 5.8 & 7.5 \\
\hline Statistical significance & NS & $*$ & $* *$ & NS \\
\hline $\begin{array}{l}\mathrm{N} \text { form } \times \mathrm{P} \text { method } \\
\text { interaction }\end{array}$ & NS & NS & NS & NS \\
\hline
\end{tabular}

${ }^{\mathrm{z}}$ All fertigated at rate of $57 \mathrm{~g} \mathrm{~N} /$ tree per year in eight weekly applications.

yP applied as $36 \mathrm{~g} \mathrm{P} /$ tree as MAP in planting hole at planting time only or as $36 \mathrm{~g} \mathrm{P} /$ tree in year 1 and $18 \mathrm{~g} \mathrm{P/tree} \mathrm{in} \mathrm{years} 2$ and 3 fertigated in eight weekly applications during May and June.

'Mean separation by Duncan's multiple range test only when ANOVA significant.

$\because$ Mean separation at $P=0.05$ or 0.01 , respectively. NS $=$ not significant.

1). The positive effect of $\mathrm{Ca}\left(\mathrm{NO}_{3}\right)_{2}$ on tree vigor by the end of the second growing season likely resulted from reduced soil acidification, which previously has been associated with $\mathrm{Ca}\left(\mathrm{NO}_{3}\right)_{2}$ $\mathrm{N}$ fertilization (Lord et al., 1981). Trees receiving annual soluble $\mathrm{P}$ applications were larger until the end of the second growing season than those receiving a single $\mathrm{P}$ application at planting time. Increased early tree vigor has previously been reported after application of MAP fertilizer to the planting hole of apple trees replanted on old orchard sites (Neilsen and Yorston, 1991). Fertigation with $\mathrm{P}$ is effective for improving tree vigor and requires less labor than a single planting hole $\mathrm{P}$ application. However, none of the variables affected tree size by the end of the third growing season. Thus, form of applied $\mathrm{N}$ fertilizer or method and time of $\mathrm{P}$ application had few-long lasting effects on tree growth.

Form of fertigation-applied $\mathrm{N}$ had little effect on tree $\mathrm{N}$ and $\mathrm{P}$ nutrition, although application of $\mathrm{Ca}\left(\mathrm{NO}_{3}\right)_{2}$ resulted in lower leaf $\mathrm{N}$ in the first year and lower fruit $\mathrm{N}$ and $\mathrm{P}$ in the first fruiting year (year 2, Table 2). In contrast, annual fertigation with $\mathrm{P}$ had a more consistent effect than a single planting-time $\mathrm{P}$ application on tree $\mathrm{N}$ and $\mathrm{P}$ nutrition with $\mathrm{P}$-fertigated trees having higher leaf $\mathrm{N}$ in year 1 and fruit $\mathrm{N}$ in year 2 (Table 2). Leaf and fruit $\mathrm{P}$ were always significantly increased by fertigation with $\mathrm{P}$ except for leaf $\mathrm{P}$ in year 2. Phosphorus was more effective in the first year, when it was applied by fertigation, thus less $\mathrm{P}$ fertilizer would be required. Leaf and fruit $\mathrm{N}$ and $\mathrm{P}$ concentrations declined over time as trees began fruiting, despite the annual application of $\mathrm{N}$ and $\mathrm{P}$ via fertigation. By the 3rd year, the decline was most pronounced for leaf $\mathrm{P}$ concentrations, which were $\approx 50 \%$ of first-year values. The marked decline in leaf $\mathrm{P}$ concentration after the first year has previously been observed after application of $150 \mathrm{~g}$ of MAP in the planting hole (Neilsen and Yorston, 1991). Apparently, a similar decline in leaf $\mathrm{P}$ values also occurs after the first year despite continued annual fertigation with $\mathrm{P}$. Although fertigation with $\mathrm{P}$ beyond 
Table 2. Effect of form of $\mathrm{N}$ and type of $\mathrm{P}$ application on 'Jonagold' and 'McIntosh' leaf $\mathrm{N}$ and $\mathrm{P}$ concentration and 'Jonagold' fruit $\mathrm{N}$ and $\mathrm{P}$ concentration during the first three growing seasons.

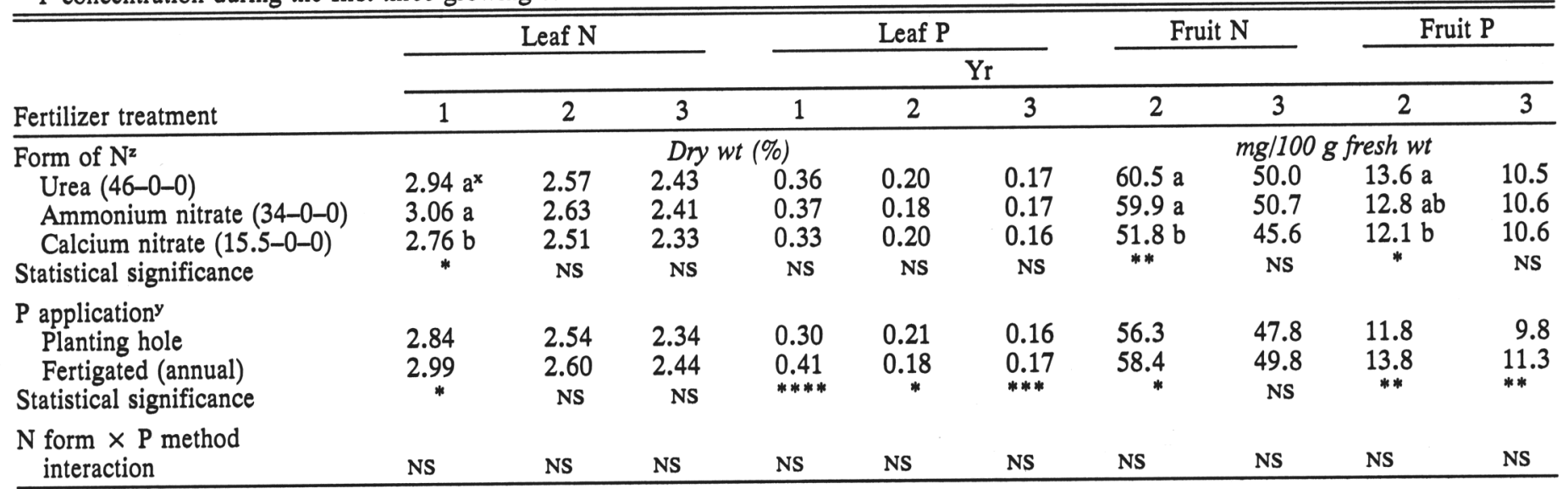

${ }^{2}$ All fertigated at rate of $57 \mathrm{~g} \mathrm{~N} /$ tree per year in eight weekly applications during May and June each year.

yP applied as $36 \mathrm{~g} \mathrm{P} /$ tree as MAP in planting hole at planting time only or as $36 \mathrm{~g} \mathrm{P} /$ tree in year 1 and $18 \mathrm{~g} \mathrm{P} /$ tree in years 2 and 3 fertigated in eight weekly applications during May and June.

xMean separation by Duncan's multiple range test only when ANOVA significant.

$\because, \cdots, \cdots, \cdots$ Mean separation at $P=0.05,0.01,0.001$, or 0.0001 , respectively. $\mathrm{NS}=$ nonsignificant.

the first season does not appear to be effective in maintaining high leaf $\mathrm{P}$ concentration, $\mathrm{P}$ fertigation in successive seasons enhances fruit $\mathrm{P}$ concentration over a single planting hole $\mathrm{P}$ application in the first year. This procedure may offer an alternative to foliar sprays (Webster and Lidster, 1986) for augmenting low fruit $\mathrm{P}$ concentrations to avoid low-temperature fruit disorders in 'McIntosh' apples.

Trees fertigated with $\mathrm{Ca}\left(\mathrm{NO}_{3}\right)_{2}$ had higher leaf $\mathrm{Ca}$ in years 2 and 3 , although in year 3 the effect was measured only for trees also fertigated with $\mathrm{P}$ (Table 3). Leaf $\mathrm{Mg}$ concentrations were decreased in years 1 and 2 by $\mathrm{Ca}\left(\mathrm{NO}_{3}\right)_{2}$ applications. The lack of an effect on leaf $\mathrm{K}$ implies that $\mathrm{Mg}$ was affected more by an increased $\mathrm{Ca}$ supply than was $\mathrm{K}$. Fertigation with $\mathrm{Ca}\left(\mathrm{NO}_{3}\right)_{2}$ increased fruit $\mathrm{Ca}$ relative to other forms of $\mathrm{N}$ in the first fruiting year, whereas fruit $\mathrm{Mg}$ and $\mathrm{K}$ were unaffected (data not shown).
The higher fruit $\mathrm{Ca}$ in year 2 occurred despite late season foliar Ca spray applications to all treatments in this orchard.

Incidence of storage disorders was especially low in the first fruiting year, with $0.6 \%$ breakdown, $0.9 \%$ bitter pit, and $3.5 \%$ rots. Similar figures for the second fruiting year averaged $6.7 \%$, $0.5 \%$, and $33 \%$, respectively. With the exception of rots, fruit quality was uniformly good. Firmness, SSC, acidity, and disorders of 'Jonagold' fruit after 4 months of air storage plus a shelf life test were unaffected by the treatments (data not shown). Klein and Spieler (1987) also found no differences in fruit mineral composition, acidity, $\mathrm{SSC}$, and firmness in $\mathrm{NH}_{4}$ vs. $\mathrm{NO}_{3}$ $\mathrm{N}$ fertigated 'Anna' apple.

The importance of fruit $\mathrm{Ca}$ concentration to rotting of 'Jonagold' fruit was indicated by the association of lower incidence of fruit disorders in year 2 when average fruit $\mathrm{Ca}$ concentration

Table 3. Effect of form of $\mathrm{N}$ and type of $\mathrm{P}$ application on 'Jonagold' and 'McIntosh' leaf $\mathrm{Ca}, \mathrm{Mg}, \mathrm{K}$, and Mn concentration and 'Jonagold' fruit $\mathrm{Ca}$ concentration during the first three growing seasons.

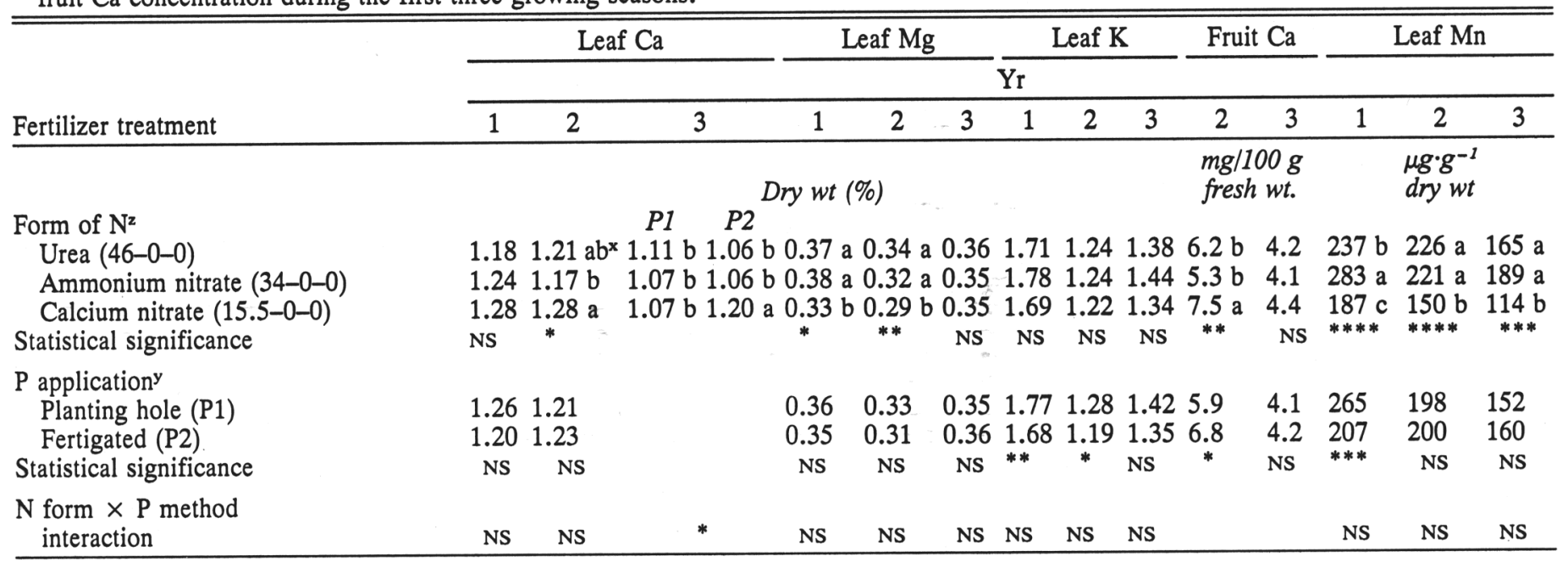

${ }^{z}$ All fertigated at rate of $57 \mathrm{~g} \mathrm{~N} /$ tree per year in eight weekly applications during May and June each year.

yP applied as $36 \mathrm{~g} \mathrm{P} /$ tree as MAP in planting hole at planting time only or as $36 \mathrm{~g} \mathrm{P} /$ tree in year 1 and $18 \mathrm{~g} \mathrm{P} /$ tree in years 2 and 3 fertigated in eight weekly applications during May and June.

xMean separation by Duncan's multiple range test only when ANOVA significant.

$*, * *, * * *, * * *$ Mean separation at $P=0.05,0.01,0.001$, or 0.0001 , respectively. NS $=$ nonsignificant. 
was higher (Table 3). The reduction in the number of foliar $\mathrm{Ca}$ sprays from 10 (year 2) to five (year 3) may have decreased fruit $\mathrm{Ca}$ concentration more than $\mathrm{Ca}\left(\mathrm{NO}_{3}\right)_{2}$ had increased it in year 2. Thus, although fertigation with $\mathrm{Ca}\left(\mathrm{NO}_{3}\right)_{2}$ may augment fruit concentration, in agreement with the results of Raese and Staiff (1983) for pears (Pyrus communis L.), this effect was overshadowed by increases resulting from foliar spray applications. Calcium $\left(\mathrm{NO}_{3}\right)_{2}$ has failed to increase fruit $\mathrm{Ca}$ status in other field studies involving broadcast $\mathrm{N}$ fertilizer application to apples (Lord et al. 1981; Miller and Glenn, 1985).

Fertigation with $\mathrm{P}$ increased fruit $\mathrm{Ca}$ concentration in the first fruiting year, but decreased leaf $\mathrm{K}$ concentrations in the first two growing seasons relative to a single $\mathrm{P}$ application at planting time. Decreased leaf $\mathrm{K}$ has been previously observed in planting hole $\mathrm{P}$ application experiments and associated with increased crop load (Neilsen and Yorston, 1991).

The most important micronutrient effect associated with the experimental treatments was for $\mathrm{Mn}$. The application of $\mathrm{Ca}\left(\mathrm{NO}_{3}\right)_{2}$ consistently reduced leaf $\mathrm{Mn}$ concentration relative to urea or $\mathrm{NH}_{4} \mathrm{NO}_{3}$, likely by preventing soil $\mathrm{pH}$ decline. The effectiveness of $\mathrm{Ca}\left(\mathrm{NO}_{3}\right)_{2}$ fertilizer for reducing $\mathrm{Mn}$ uptake and preventing soil $\mathrm{pH}$ decline would suggest that this fertilizer would be a preferred $\mathrm{N}$ source if $\mathrm{Mn}$ toxicity were likely to be a problem. Although it is cheaper to adjust soil $\mathrm{pH}$ using lime, $\mathrm{pH}$ correction may be difficult where localized acidity develops to some depth beneath trickle irrigation emitters. Further, the effectiveness of $\mathrm{Ca}\left(\mathrm{NO}_{3}\right)_{2}$ for ameliorating internal bark necrosis and correcting a $\mathrm{Ca} / \mathrm{Mn}$ imbalance of 'Delicious' apple trees (Hoyt, 1988) should be tested.

Phosphorus application also affected Mn nutrition with lower leaf Mn concentration measured for P-fertigated trees in the first year. Increased leaf $\mathrm{Mn}$ concentration as a consequence of fertilizer-induced acidification of planting hole soil has previously been measured after MAP fertilization (Neilsen and Yorston, 1991). Fertigation with similar amounts of $P$ reduced first-year tree $\mathrm{Mn}$ concentration-a possible benefit if $\mathrm{Mn}$ concentrations are already high.

In summary, newly planted apple trees were responsive to form of $\mathrm{N}$ applied by fertigation. Most effects were associated with application of $\mathrm{Ca}\left(\mathrm{NO}_{3}\right)_{2}$. Urea, $\mathrm{NH}_{4} \mathrm{NO}_{3}$, and $\mathrm{Ca}\left(\mathrm{NO}_{3}\right)_{2}$ would be acceptable $\mathrm{N}$ sources for fertigation with an advantage to use $\mathrm{Ca}\left(\mathrm{NO}_{3}\right)_{2}$ when soil $\mathrm{pH}$ is low and $\mathrm{Mn}$ toxicity is a problem. Annual fertigation with $\mathrm{P}$ was labor efficient and also generally more effective than planting hole $\mathrm{P}$ application. Thus, a lesser amount of $\mathrm{P}$ applied by fertigation would be sufficient to achieve similar improvements in tree vigor and $\mathrm{P}$ nutrition. None of the forms of $\mathrm{N}$ nor method and times of $\mathrm{P}$ application significantly affected tree vigor by the 3rd year nor fruit quality or storage disorders.

\section{Literature Cited}

British Columbia Ministry of Agriculture and Fisheries. 1989. Tree fruit production guide for the interior district. Country Life, Surrey, B.C.

Bussi, C., J.G. Huguet, and H. Defiance. 1991. Fertilization scheduling in peach orchards under trickle irrigation. J. Hort. Sci. 66:487493.

Goode, J.E., K.H. Higgs, and K.J. Hyrycz. 1978. Trickle irrigation of apple trees and the effects of liquid feeding with $\mathrm{NO}_{3}$ - and $\mathrm{K}+$ compared with normal manuring. J. Hort. Sci. 53:307-316.

Haynes, R.J. 1985. Principles of fertilizer use for trickle irrigated crops. Fert. Res. 6:235-255.

Hoyt, P.B. 1988. The relationship of internal bark necrosis in 'Delicious' apples to tree characteristics and soil properties. Commun. Soil Sci. Plant Anal. 19:1041-1048.

Klein, I. and G. Spieler. 1987. Fertigation of apples with nitrate or ammonium nitrogen under drip irrigation. I. Tree performance. Commun. Soil Sci. Plant Anal. 18:311-322.

Lau, O.L. 1983. Effects of storage procedures and low oxygen and carbon dioxide atmospheres on storage quality of 'Spartan' apples. J. Amer. Soc. Hort. Sci. 108:953-957.

Lord, W.J., J.H. Baker, and R.A. Damon, Jr. 1981. Soil, tree, and fruit responses to lime and to type and timing of nitrogenous fertilizer applications under 'Sturdeespur Delicious' apple trees. J. Amer. Soc. Hort. Sci. 106:616-619.

Miller, S.S. and D.M. Glenn. 1985. Influence of various rates of $\mathrm{Ca}\left(\mathrm{NO}_{3}\right)_{2}$ fertilizer and soil management on young apple trees. J. Amer. Soc. Hort. Sci. 110:237-243.

Neilsen, G.H., E.J. Hogue, and P. Parchomchuk. 1990. Flowering of apple trees in the second year is increased by first-year P fertilization. HortScience 25:1247-1250.

Neilsen, G.H. and J. Yorston. 1991. Soil disinfection and monoammonium phosphate fertilization increase precocity of apples on replant problem soils. J. Amer. Soc. Hort. Sci. 116:651-654.

Raese, J.T. and D.C. Staiff. 1983. Effect of rate and source of nitrogen fertilizers on mineral composition of d'Anjou pears. J. Plant Nutr. 6:769-779.

Smith, M.W., A.L. Kenworthy, and C.L. Bedford. 1979. The response of fruit trees to injections of nitrogen through a trickle irrigation system. J. Amer. Soc. Hort. Sci. 104:311-313.

Webster, D.H. and P.D. Lidster. 1986. Effects of phosphate sprays on McIntosh apple fruit and leaf composition, flesh firmness and susceptibility to low temperature disorders. Can. J. Plant Sci. 66:617626.

Yogaratham, N., M. Allen, and D.W.P. Greenham. 1981. The phosphorus concentration in apple leaves as affected by foliar application of its compounds. J. Hort. Sci. 56:255-260. 